\title{
Empirically Determined Passenger Ferry Navigable Routes within Lagos Lagoon
}

\author{
Q. A. Adejare ${ }^{1}$, J. O. Olusina ${ }^{2}$ J. B. Olaleye ${ }^{2}$ \\ ${ }^{1}$ Department of Surveying and Geo-informatics, University of Technology, Ota, Ogun State, Nigeria. \\ ${ }^{2}$ Department of Surveying and Geo-informatics, University of Lagos, Akoka, Yaba, Lagos, Nigeria.
}

\begin{abstract}
Hydrographic surveys define shorelines and depths of lakes, streams, oceans, reservoirs, and other bodies of water. Sea surveying is associated with port and offshore industries and the marine environment, including measurements and marine investigations made by ship-borne personnel. In addition, accurate measurement and modelling of hydrographic information is important to control waterways boat services with existing roadway transportation services. This paper attempts an empirical analysis of hydrographic data to simulate waterway navigable route within Lagos Lagoon with a minimum under-keel clearance that must be maintained by vessel transiting a port as well as berthing. The field investigation was conducted between September 2015 and March 2016 to determine river bed topography with the deployment of DGPS receivers, Single beam SDE 28S echo sounder, speed boat, tidal observation and reduction. Hypack 2008 and Arc GIS software was used for data sorting, extraction and processing. It was observed that depth within the project area ranges between $0.0 \mathrm{~m}$ to $14.82 \mathrm{~m}$ when referred to the Lagos datum. Furthermore, waterway navigable chart was developed based on prevailing river bed topography along the study corridors as well as passenger ferry draught constraint. From this study, derived depths were analysed in form of graphs and charts that provides a suitable framework to support ferry transportation services within Lagos Lagoon as a complimentary mode to the dominantly depended road transportation services. Therefore, periodic hydrographic survey of the navigable routes is recommended specifically to identify possible channel accretion.
\end{abstract}

KEYWORDS: Navigable routes, hydrographic information, empirical analysis, under-keel clearance, river bed, topography

[Received May 04 2017; Revised November 02 2017; Accepted November 18 2017]

\section{INTRODUCTION}

Traffic congestion is a very well-known transportation problem in Lagos Metropolis which create unpleasant challenges to urban dwellers. Lagos is known not only as the commercial nerve centre of Nigeria but also for severe traffic congestion problems. The rapid urbanization in Lagos State is largely unplanned and has resulted in an unprecedented rate of motorization coupled with insufficient road network facilities. Yan et. al., 2016 stated that in adequate road capacity and high traffic volume has resulted in severe traffic congestion in Jiangsu province, China. Road network in Lagos Metropolis are frequently congested with over 222veh/km (Taiwo, 2005; Odeleye and Oni, 2007; Olagunju 2015) against $11 \mathrm{veh} / \mathrm{km}$ Roadway Level of Service (LOS) for a category A (TRB, 2006). Furthermore, due to road side developmental activities (urban furniture, fly over) and land use, it becomes almost impossible to further widening the road network to increase the roadway capacity (Chowdhury et. al., 2014). In addition to insufficient road network, road side activities, in disciplined attitude of road users, mixture of different type of vehicles, segregated BRT travel corridor and lack of coordinated transportation management, reduces the existing roadway capacity and results in huge road congestion in Lagos metropolis.

*Corresponding author’s e-mail address: quadriadejare@yahoo.com
In an effort to address this urban challenges, LAMATA (2014) highlighted positive steps proposed for dealing with traffic congestion contained in their 30-years transportation improvement plan. Essentially, the steps include light rail schemes and BRT bus services in Lagos State. However, according to (Edelman, 2015) given the existing land use structure of Lagos, the integration of light rail schemes and BRT services is not likely to ameliorate the problems of traffic congestion. He suggested a system which will include non-land based systems as a more assuring way to solve the problem. Moreover, Lagos State is naturally endowed with navigable creeks (Lighthouse creek, Badagry creek, Five Cowries creek, Agboyi creek) and lagoons (Ologe Lagoon, Ogun River, Majidun River, Lagos Lagoon, Kuramo water) that are suitable for urban transit services.

Larbie (2014) emphasised the need to conduct hydrographic surveys on our water bodies to determine its safety for transportation. The use of the water body for transportation will reduce the over dependency on road transportation by creating another alternative thereby creating job for the people. The study concludes that water transportation system can be one of the cost effective and safest modes of transportation in Ghana. Therefore, navigational charts are the foundation of ocean transportation (NOAA Hydrographic Survey Priorities 2012). In doi: http://dx.doi.org/10.4314/njtd.v14i2.6 
bathymetric survey, charts are produced to support safety of surface or sub-surface as contour lines and such charts provides surface navigational information (Chukwu and Badejo 2015). Hydrographic survey supports a variety of marine functions: port and harbour maintenance (dredging), coastal engineering (subsidence assessments and restoration projects), coastal management and offshore resources development (Larbie, 2014). In 2008 hydrographic survey of Asa river in Ilorin was conducted to produce rescue map to mitigate flood disasters (Adeleke et. al., 2013). The study concludes that hydrographic survey had great potential to improve river channel for flood mitigation/control and remedial work.

Colin (1998) asserted that travel by water predates the wheel and remains a vital form of transport for millions of people in rural and urban areas. Though inland water transport (IWT) is comparatively cheaper and more efficient means of transportation in riverine community. It is a mode that is faced with neglect and is undervalued. Furthermore, inland waterways sector has always been neglected to the detriment of the navigable rivers and Lagoons in Lagos State and riverine dwellers (Asenime, 2008; Adejare et. al., 2011). Asenime (2008) in a study of inland water transportation in Lagos Metropolis believes that Lagos State has the networkcapacity to carry commuters to almost every part of the Metropolis, though it is currently grossly under-utilized. Sufficient information, on feasible routes based on navigable chart is lacking. The databank is in poverty of data on the characteristics of water bodies, their positions, routing that could ease boat movement and ease potential investment in water transportation system. The current ferry system in Lagos State is lacking in size, accessibility and therefore unable to offer the required attraction of commuters. Table 1 shows Water Taxi types and their characteristics.

However, a well-developed water transportation system can assist in the reduction of road congestion and thus increase the life span of the roads. It is in view of these and the need to address these ills that this research is prompted. Therefore, this paper attempts to determine the most practicable water navigable route within Lagos Lagoon based on empirically determined hydrographic data. Similarly, the primary objective of hydrographic survey is to obtain basic data for the compilation of bathymetric charts with emphasis on features that may affect safe navigation. In addition to measuring water depths, hydrographic surveys identify hazards to navigation, delineate channels, and verify aids to navigation and landmarks (Egbuh, 2006). Water depths are normally measured using either single beam echo sounder or multi beam echo sounder. Single beam echo sounder is the most common technique used in port and harbour surveys and will continue to give valid results when used correctly in a well- planned and executed survey (FIG, 2010). The majority of sensors used for depth determination use acoustic waves. Single beam echo sounder acquired data directly underneath the transducer (El-Hattab, 2014).
Table 1: Water Taxi Types and their Characteristics.

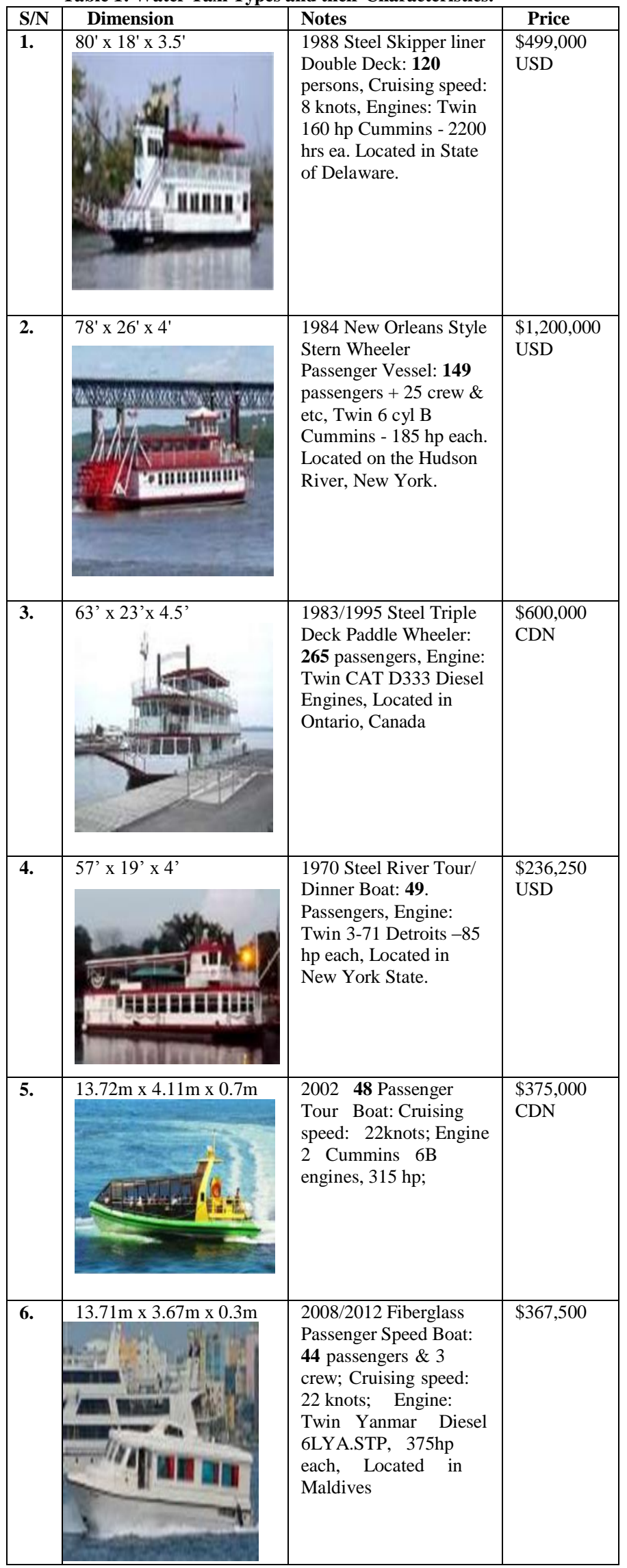




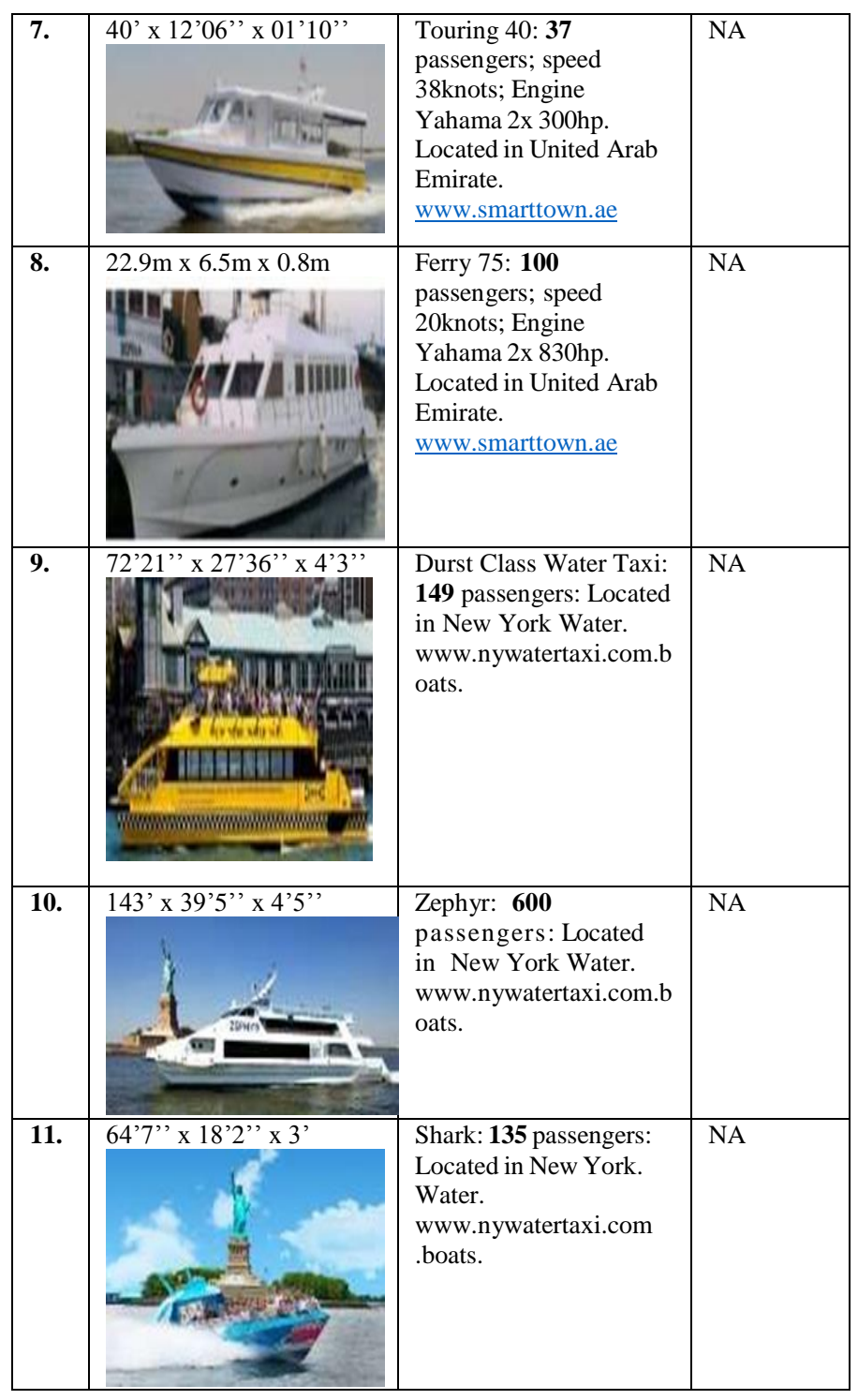

Source Serial No. 1-6: Scruton Marine Services:

www.scrutonmarine.com: Assessed on 24 ${ }^{\text {th }}$ January, 2017.

I ne stuay area Ior tnis researcn is Lagos, witn particular focus on Lagos Lagoon. Lagos is one of the African megacities. It is located in south western Nigeria on the west coast of Africa, within latitudes $6^{0} 23^{\prime} \mathrm{N}$ and $6^{\circ} 41^{\prime} \mathrm{N}$ and longitudes $2^{0} 42^{\prime} \mathrm{E}$ and $4^{0} 00^{\prime} \mathrm{E}$. Lagos State is flanked to the north and east by Ogun State, in the west by the Republic of Benin and to the south by the Atlantic Ocean/Gulf of Guinea. A considerable part of Lagos State is made up of Lagoon and creeks as shown in Figure 1. Lagos Lagoon covers a total area of about $426 \mathrm{~km}^{2}$ with a coastline and inland waterways; with an average depth of about $1.6 \mathrm{~m}$ throughout the year with negligible or insignificant variations.

On the west of the Lagoon (south-west of the harbour) there are several creeks; these are the Lighthouse creek, Ologe Lagoon, the Badagry creek leading to Tomaro Island, the main waterway leading to Badagry (Port Novo and Cotonou). Another creek joining the southern part of the main Lagos Lagoon to the Atlantic through Victoria Island is called Five Cowries creek. The North East of lagoon is bounded with Ikorodu local port that leads to Epe. Also at that region, there are several inlets from Ogun River, Majidun River and Agboyi creek. A sub- lagoon of the Lagos Lagoon lies to the east of the harbour bound, and the bar beach between the Atlantic Ocean and the Lagoon is called the Kuramo waters.

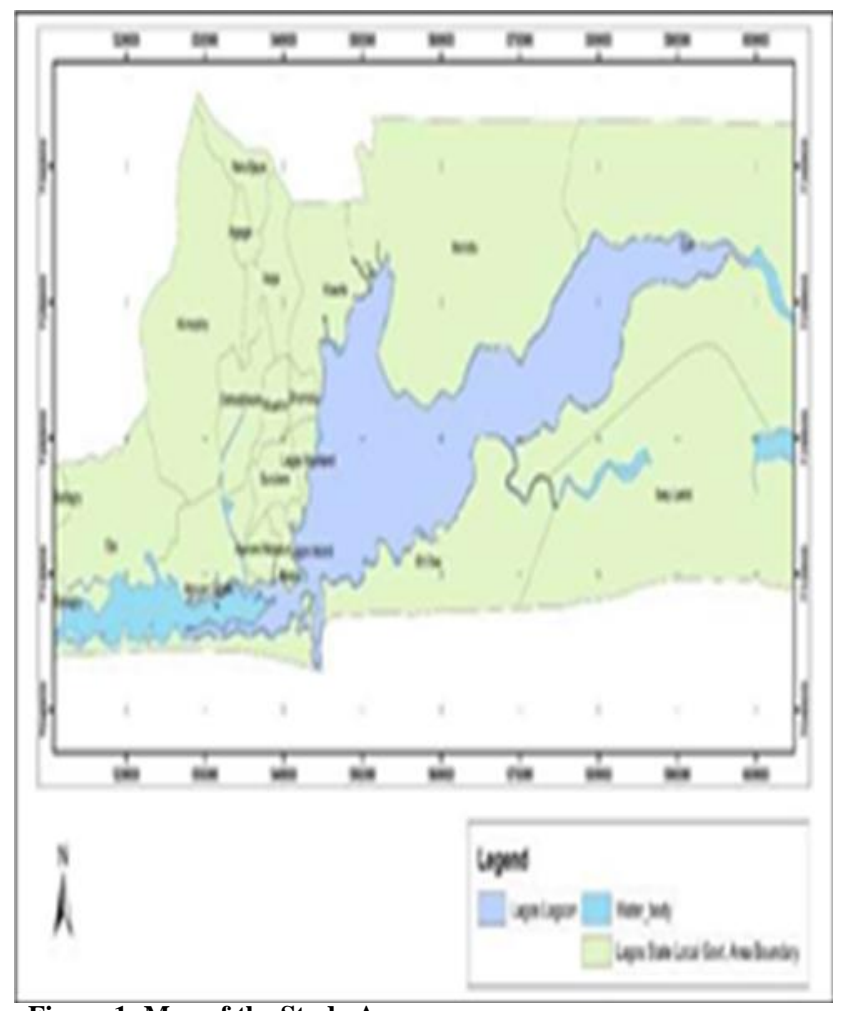

Figure 1: Map of the Study Area

\section{MethodOLOGY}

This involves data acquisition, processing, data quality verification. The Bathymetry survey was carried out using South SDE-28S Echo sounder, DGPS receiver and Hypack 2008 Hydrographic software. The South Echo sounder is a fully automated echo sounder. It has a Windows Operating System and a software called PowerNav for navigation. It has the capability of showing the position of the boat on the navigational chart. It is also capable of centrimetric accuracy. The echo sounder was calibrated on site. The transducer was responsible for sending and receiving signals from the seabed and transmitting same to the echo sounder. The result is a digital display of position and depth of location at any particular instance. The raw data acquired by the South SDE-28S Echo sounder was sorted by Power Nav software. The sorted data were then further processed using Hypack 2008 software.

The soundings obtained in the field were reduced to standard reference plane, by subtracting from them the height of the tide at the time they were taken. The measured depths were automatically generated, downloaded and processed to true depth by the removal of the tidal effect. The true depths were extracted from sounding data using eqn (1) according to Habert (1984) and Ojinnaka (2007). 


$$
\mathrm{Z}_{\mathrm{y}}=\mathrm{Z}_{0}+1 / 2 \mathrm{C}_{\mathrm{v}} \Delta \mathrm{t}
$$

where: $\mathrm{z}_{\mathrm{V}}=$ true depth, $\mathrm{z}_{0}=$ transducer depth, $\mathrm{c}_{\mathrm{V}}=$ mean speed, $\Delta \mathrm{t}=$ time interval.

\section{True Depth $\left(z_{v}\right)$}

This is the real value of the depth of the riverbed topography. It is obtainedafter applying corrections to the raw data obtained from sounding as shown in eqn (2).

$$
\mathrm{Z}_{\mathrm{y}}=\mathrm{Z}_{0}+1 / 2 \mathrm{C}_{\mathrm{v}} \Delta \mathrm{t}-\mathrm{Tp}
$$

$\mathrm{Tp}=$ Predicted Tidal reading. The predicted tidal values were obtained from the Nigeria Navy Tidal Prediction Table for 2015 and 2016 where the predicted times and heights of high and low water are extracted from, and various tidal values for the time of soundings were interpolated from the high and low water (Nigeria Navy Tidal Prediction Table for 2015: 2016).

All water depths have been reduced to Chart datum. Therefore, this is the actual value of the river bed topography obtained after the removal of the effect of tide and necessary correction and other phenomenon that constitute the raw data obtained from the sounding. The bathymetric and positioning data were plotted in AutoCAD software environment. Finally, channel design (navigable charts) was carried out using AutoCAD 3D, Arc GIS software. ArcGIS was used for data integration, analysis and creation of water network for the proposed routes. Furthermore, the design proposed a minimum channel depth of $1.0 \mathrm{~m}$ below Chart datum for safe marine transportation based on water taxi constraints provided in Table 1 . The vertical reference levels are compared to statistical tidal data to determine the minimum channel depth required for safety of navigable commuters' ferry services within Lagos Lagoon.

The topologic structure of this transportation network involves the reduction of the link pattern to its most basic elemental form. Furthermore, Figure 2 depicts water bed

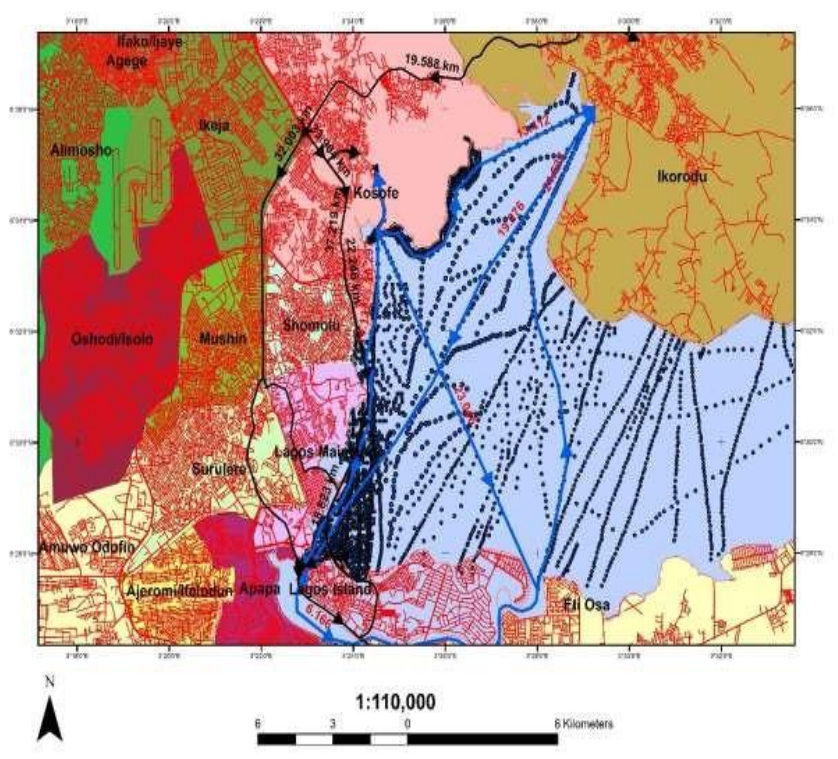

Figure 2: Water bed topography, existing road network and proposed waterway routes with their attributes. topography, existing road network and proposed water routes with ferry draught of $1.0 \mathrm{~m}$ based on bathymetric results, water taxi characteristics and existing Jetty facilities at the terminals respectively.

\section{RESULTS AND DISCUSSION}

Based on this study, the proposed channel was designed in line with the view of reality, accurate spatial data observation and detailed examination of the navigation charts derived. In addition, Figures 3 - 9 are the vertical profiles from this study that show changes in river bed elevation which were used to determined water transportation navigable routes along the study corridors as presented.

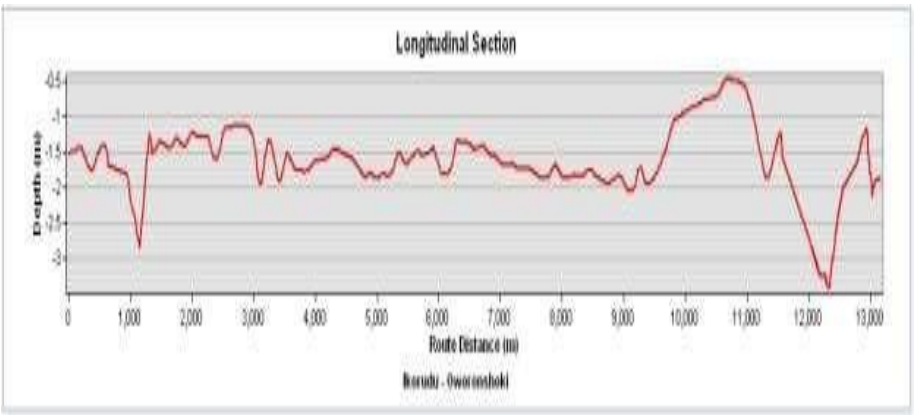

Figure 3: Vertical profile from Ikorodu to Oworonshoki [e1].

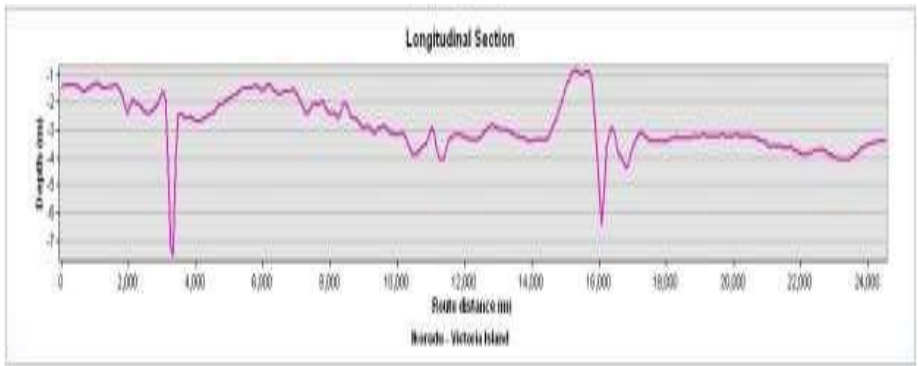

Figure 4: Vertical profile from Ikorodu to Victoria Island [e2].

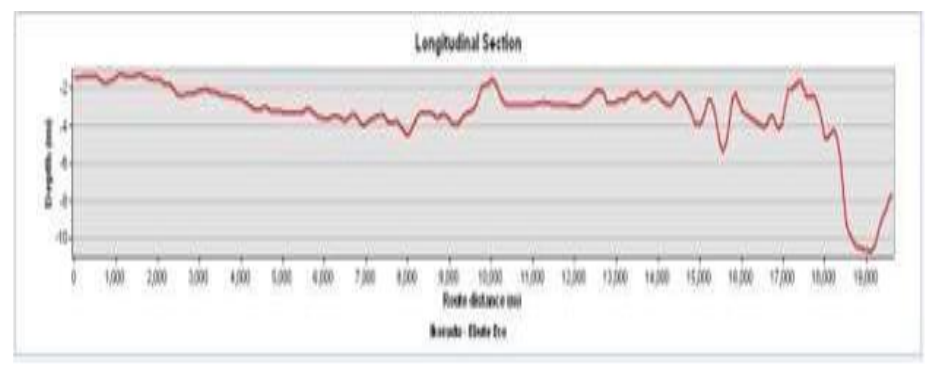

Figure 5: Vertical profile from Ikorodu to Ebute Ero [e3].

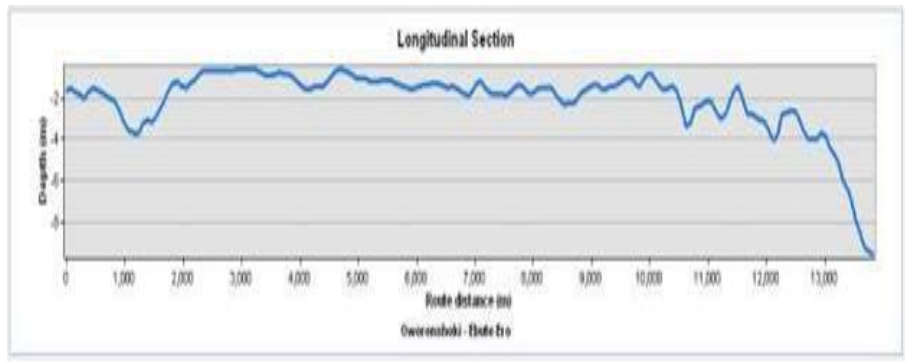

Figure 6: Vertical profile from Oworonshoki to Ebute Ero [e4]. 


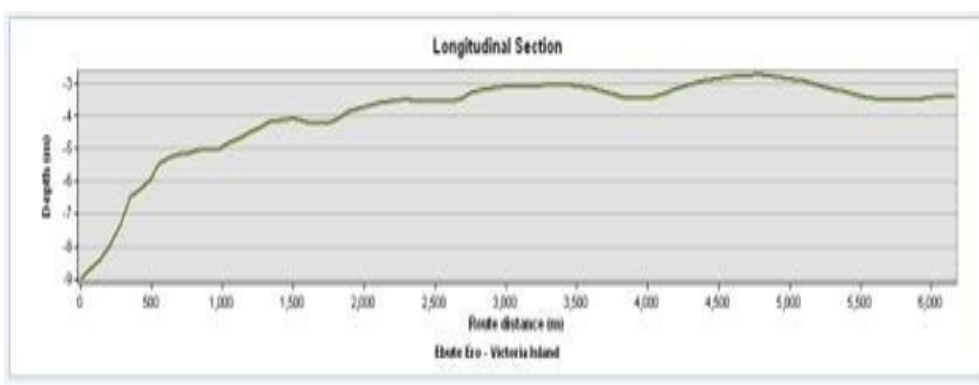

Figure 7: Vertical profile from Ebute Ero to Victoria Island [e5].

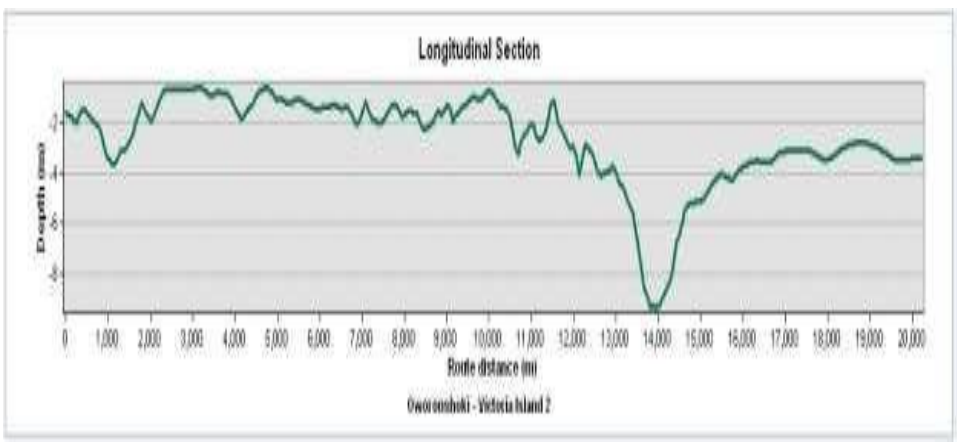

Figure 8: Vertical profile from Oworonshoki to Victoria Island [e6].

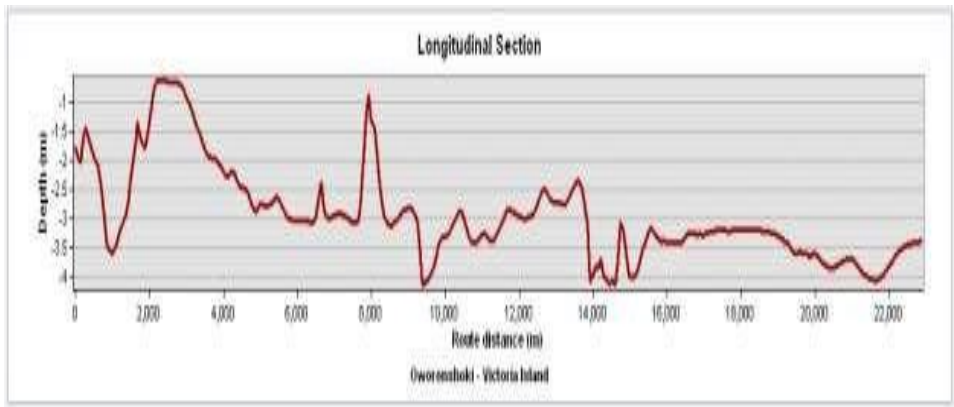

Figure 9: Vertical profile from Oworonshoki to Victoria Island [e6].

Hydrographic data for part of Lagos lagoon has been acquired and processed for electronic nautical charts, showing the nature and form of the lagoon areas, depth of the water and general character and configuration of river bed, identification of dangers to navigation, rise and fall of the tides and cautions to navigation in Lagos lagoon were also presented. Taking into account that inland waterways vessel draught should be less than water depth, as well as air clearance; currently in Lagos lagoon, the navigable draught is less than 2 meters. From the bed topography, many of the ferry terminals require new and maintenance dredging to maintain efficient and effective navigable waterways for the intending ferry services.

Figure 3 shows longitudinal profile that revealed depth changes along Ikorodu to Oworonshoki proposed navigable route. Depth values in meter were plotted against route distances at $1 \mathrm{~km}$ horizontal interval along this section river bed topography is less than $1 \mathrm{~m}$ between chainage $10 \mathrm{~km}$ to $11 \mathrm{~km}$. Similarly, Figure 4 indicated that within chainage 14 $\mathrm{km}$ to $16 \mathrm{~km}$ water depth was less than $1 \mathrm{~m}$. Along this section depth values in meter were plotted against route distances at 2 $\mathrm{km}$ horizontal interval. From chainage $0 \mathrm{~km}$ to $2 \mathrm{~km}$, at chainage $10 \mathrm{~km}$ and between chainage $17 \mathrm{~km}$ to $18 \mathrm{~km}$ water depth were less than $2 \mathrm{~m}$ in Figure 5, depth values in meter were plotted against route distances at $2 \mathrm{~km}$ horizontal interval.

Also, from section $2 \mathrm{~km}$ to $11 \mathrm{~km}$ in Figure 6 water depth was less that $2 \mathrm{~m}$, a small increase in depth is required along this route, depth values in meter were plotted against route distances at $1 \mathrm{~km}$ horizontal interval. Similarly, in Figure 7 section $4.5 \mathrm{~km}$ to $5 \mathrm{~km}$ revealed that depth values are less than $3 \mathrm{~m}$ and depth information were plotted against route distances at 500 meter horizontal interval. Furthermore, from Figure 8 section $2 \mathrm{~km}$ to $10.5 \mathrm{~km}$ had water depth less than $2 \mathrm{~m}$ and depth values in meter were plotted against route distances at $1 \mathrm{~km}$ horizontal interval. Finally, in Figure 9 chainage $2 \mathrm{~km}$ to $3 \mathrm{~km}$; between chainage $7 \mathrm{~km}$ to $8 \mathrm{~km}$ water depth are less than $1 \mathrm{~m}$ immediately after this two sections water depth are sufficient for ferry transportation services. From the depth profile indicated in Figures 3 - 9, double deck ferry with high capacity and flatbed are proposed to cope with the existing river bed terrain configuration. However, high capacity ferry passenger waterway transportation can be doubled by small increase in depth by dredging.

\section{CONCLUSION}

The acquired bathymetric survey data was obtained in order to create organized graphic portrayal (geographic and numerical data) of the marine environment for nautical charts which are an end product of hydrographic survey. Lagos lagoon has many restrictions that greatly, influence navigation. The most important restrictions are the water depth and the bridge height. The depth within the project area ranges between $0.0 \mathrm{~m}$ and $14.82 \mathrm{~m}$ when referred to the Lagos datum. From the study, the summary of the navigable restriction is given below:

i. Water depth: In the lagoon, several sections have water depth less than 2 meters. At the harbour entrance, the water depth is above 5meters, and the maximum is above 19 meters.

ii. From the bed topography, many of the ferry terminals require new and maintenance dredging to maintain efficient and effective navigable waterways for the intending ferry services. Significant capital improvements in the way of dock and terminal facilities would be required at all proposed commuter ferry locations except at Ikorodu jetty.

iii. However, bathymetric data for part of Lagos lagoon has been acquired and processed for electronic nautical charts, showing the nature and form of the lagoon areas, depth of the water and general character and configuration of river bed, identification of dangers to navigation, rise and fall of the tides and cautions to man -made aids to navigation in Lagos lagoon were also presented.

iv. Waterway transportation route was designed based on empirically determined hydrographic data acquisition, processing and analysis that provides a suitable framework to support ferry transportation services within Lagos Lagoon as a complimentary 
mode to the dominantly depended road transportation services.

\section{RECOMMENDATIONS}

Based on empirically determined passenger ferry navigable routes determined in this study, the following recommendations are made:

i. Hydrographic information provides a suitable framework to support waterway transportation services within Lagos Metropolis. Government should improve necessary facilities to support waterway transportation services along the study corridors.

ii. All human economic activity creates noise in the waters and presumably constant levels of noise have the potential to negatively impact the marine life in heavily traffic waterways. However, long-term studies are needed to better understand the impact of vessel traffic on marine animals.

iii. The study of seasonal effect of water hyacinth within Lagos lagoon and it's environmental impact require careful study.

\section{REFERENCES}

Adejare, Q. A.; P. C. Nwilo, J. O. Olusina and Y. D. Opaluwa. (2011): A Study of Ferry Route Network in Lagos Lagoon - Nigeria Using Graph Theory. Journal of Geography and Regional Planning, 4(6): 326-337.

Adeleke, O. O.; Y. A. Jimoh, A. M. Ayanshola and A. S. Aremu. (2013). Role of Geomatics in the Management of Disasters and Infrastructural Failures. Ethiopian Journal of Environmental Studies and Management, 6(2): 143-148.

Asenime, C. O. (2008): A Study of Inland Waterway Transportation in Metropolitan Lagos. Unpublished P h . D . Thesis, Department of Geography a nd P lanning ( Transportation), University of Lagos, Lagos, Nigeria.

Chowdhury, M. S. A; G. Sarwar and M. B. Haque. (2014). Identifying the Factors Effecting the Choice of Waterway as an Alternative of Bandar Bazar to Tuker Bazar Route. Modern Traffic and Transportation Engineering Research, 3(2): 31-36.

Chukwu, F. N.; and Badejo, O. T. (2015). Bathymetric Survey Investigation for Lagos Lagoon Seabed Topographical Changes. Journal of Geosciences and Geomatics, 3(2): 37-43.

Colin P. (1998). Water Transportation for Rural Settlements, retrieved from www.worldbank.org.

Edelman, D. J. (2015). An Environmental Plan for Lagos, Nigeria. International Journal of Social Science, 3(1): 202-279.
Egbuh, I. N. (2006). Charting Nigerian Waters for Safer Navigation. International Hydrographic Review, 7(3): 28-35.

El-Hattab, A. I. (2014). Single Beam Bathymetric Data Modelling Techniques for Accurate Maintenance Dredging. The Egyptian Journal of Remote Sensing and Space Science, 17(2): 189-195.

Federation Internationale des Geometres. (2010). Guidelines for the Planning, Execution and Management of Hydrographic Surveys in Ports and Harbours. International Federation of Surveyors (FIG), Copenhagen, Denmark.

Habert F. A. (1984). Manual of Hydrography Volume 2 (1984). Prepared and Published by Ingenieuren Chef de l'armement f. Habert. Etablissement principal du service Hydrographique et Oceanographique de la marine. B.P.426 -29275- BREST CEDEX: XXV.2-XXV.17

Lagos Metropolitan Area Transport Authority (LAMATA) (2014): Description of Transportation Projects currently happening in Lagos. http:///www.lamata.ng.com

Larbie I. (2014). The Importance of Hydrographic Surveying in the Development of a Water/Lake Transportation System in Ghana. Paper presented at International Federation of Surveyors (FIG Congress 2014), Paper No. 7028, Kuala Lumpur, Malaysia.

Nigerian Navy Tidal Prediction Table (2015). Published by the Nigerian Navy Hydrographic Office (NNHO), Apapa, Lagos, Nigeria.

Nigerian Navy Tidal Prediction Table (2016). Published by the Nigerian Navy Hydrographic Office (NNHO), Apapa, Lagos, Nigeria.

Odeleye J. A. (2008). A study of Road Traffic Congestion in Selected Corridors of Metropolis Lagos, Nigeria. Unpublished Ph.D. Thesis, Department of Geography, University of Lagos, Lagos, Nigeria.

Olagunju K. (2015). Evaluating Traffic Congestion in Developing Countries. A Case Study of Nigeria. Paper Presented at the Chartered Institute of Logistics and Transport (CILT2015), Arusha, Tanzania.

Ojinnaka O. C. (2007). Principles of Hydrographic Surveying from Sextant to Satellite. El 'Demak Publishers Enugu, Nigeria.

Taiwo, K. (2005). The Case of Lagos: Air Quality Improvement Project. Lagos Metropolitan Area Transport Authority (LAMATA), Lagos, Nigeria.

Transportation Research Board (TRB) (2006). Highway Capacity Manual. National Research Council, Washington, D.C., U.S.A.

Yan, Y.; Z. Liu, and Y. Bie. (2016). Performance Evaluation of Bus Routes Using Automatic Vehicle Location Data. Journal of Transportation Engineering, 142(8): 1-12. 